\title{
Comparison of techniques which use the DST flow period data for evaluation of reservoir parameters
}

\section{Porównanie sposobów oceny parametrów zbiornikowych na podstawie danych zarejestrowanych podczas opróbowań rurowymi próbnikami złoża}

\author{
Tadeusz Szpunar, Paweł Budak \\ Oil and Gas Institute - National Research Institute
}

\begin{abstract}
This paper presents a comparison of techniques utilizing DST flow period data for calculation of permeability and skin. Results obtained using the commonly accepted "type curve" method and the technique presented in Szpunar (2001) are summarized. It has been demonstrated that the results of each of these methods do not differ much. Advantages and disadvantages of each technique are discussed. Our new method presented in Szpunar (2001) and developed by Szpunar and Budak (2012) may also be used for interpretation of downhole pressure or water level behavior in coal bed methane wells and water wells which do not flow to the surface after the pressure disturbance is introduced by addition or removal of water from the well. Apart from reservoir permeability and skin, the presented method enables calculation of permeability of the wellbore zone and depth of impaired/improved permeability, providing the pressure drop within the DST conduit is negligible when compared to hydrostatic pressure exerted upon reservoir by a column of liquid moving up the well. The commonly known "type curve" method does not offer such possibility. According to the authors, the "type curve" methods - in spite of their theoretical merits - provide results which are uncertain because they require adaptation of the measured curve to one of theoretical curves, the shapes of which are very similar. Summarizing - there is an acceptable agreement between permeability calculated using each of the methods discussed, but one should not expect that permeability calculated using each of the methods to be identical.
\end{abstract}

Key words: slug test, type curve method, DST flow period, dimensionless pressure, dimensionless time, wellbore storage, wellbore zone, permeability.

STRESZCZENIE: W artykule przedstawiono porównanie metod wykorzystujących dane pomiarowe okresu przypływu do rurowego próbnika złoża (rpz) do obliczenia przepuszczalności i współczynnika skin efektu. Zestawiono wyniki uzyskane przy zastosowaniu „klasycznej” metody wpasowania krzywych pomiarowych do krzywych teoretycznych oraz wyniki metody podanej w pracy Szpunara (2001). Wykazano, że wyniki obydwu metod nie różnią się w sposób istotny. Omówiono zalety i niedogodności każdej z nich. Metoda opisana przez Szpunara (2001) i rozwinięta przez Szpunara i Budaka (2012) może być zastosowana do interpretacji zachowania ciśnienia dennego lub przebiegu podnoszenia się lustra wody w otworach odwierconych w warstwach węgli oraz studniach wierconych, w których nie ma produkcji samoczynnej, co wymaga wywołania zaburzenia ciśnienia w odwiercie przez wlanie do niego lub odpompowanie z niego porcji cieczy. Poza obliczeniem przepuszczalności i współczynnika skin efektu metoda przedstawiona przez Szpunara (2001) umożliwia określenie przepuszczalności strefy przyodwiertowej oraz głębokości uszkodzenia/poprawy przepuszczalności w strefie przyodwiertowej, pod warunkiem że opory przepływu w przewodzie rurowego próbnika złoża (rpz) są pomijalnie małe. „Klasyczna” metoda określania przepuszczalności przez wpasowanie krzywej pomiarowej do krzywych teoretycznych nie stwarza takich możliwości. Ponadto, zdaniem autorów, „klasyczna” metoda wpasowania krzywych (pomimo jej teoretycznej poprawności) daje wyniki niepewne z uwagi na trudności w dopasowaniu pomierzonej krzywej zależności ciśnienia od czasu do właściwej krzywej teoretycznej, których kształt jest bardzo podobny. Podsumowując, należy stwierdzić, że istnieje akceptowalna zgodność między przepuszczalnością obliczoną przy użyciu każdej z omawianych metod. Nie należy jednak oczekiwać, że przepuszczalność obliczona każdą z tych metod będzie identyczna.

Słowa kluczowe: slug test, metoda wpasowania krzywych, dane okresu dopływu do rpz, bezwymiarowe ciśnienie, czas bezwymiarowy, efekt nagromadzenia w odwiercie, strefa przyodwiertowa, przepuszczalność.

Corresponding author: P. Budak, e-mail: pawel.budak@inig.pl

Article contributed to the Ediotr: 13.01.2020. Approved for publication: 25.05.2020 


\section{Introduction}

The purpose of this work was to illustrate the possibilities offered by technique presented in Szpunar (2001) that was used here for the interpretation of DST flow test. The method can be also used for evaluation of permeability and skin of low pressure water wells or coal bed methane wells that do not flow to the surface or for analyzing the behavior of the water table before it reaches the surface. After the drill stem tester (DST) is run into the well and the packer is set above the reservoir, the pressure within the reservoir stays at the constant level $p_{1}$ which is the reservoir pressure. The pressure above the DST master valve is $p_{o}<p_{1}$. The opening of the DST master valve would cause the reservoir fluid to flow upwards within the DST conduit. Before the fluid reaches the surface, both the flow rate and pressure opposite the reservoir change due to the increasing fluid head acting upon the reservoir. Such a situation will last until the hydrostatic pressure exerted by the liquid column balances the reservoir pressure or the fluid reaches the surface and starts to flow out from the well. An identical situation would also exist in low pressure water wells or coal bed methane wells in which the stabilized water level stays below the surface and some water is added or removed from the well. In such a case the pressure within the reservoir would restore to its initial value after some time the length of which depends mainly on reservoir permeability, thickness of reservoir, wellbore radius and volume of water added or removed. In this paper the application of this method would be restricted to DST flow test only.

Both in the case of DST tested wells and low pressure liquid wells the evaluation of reservoir parameters requires measuring the relation between the pressure opposite to the reservoir and the time recorded before the fluid reaches the surface or the liquid table stabilizes within the well.

Usually, the "type curve method" - presented for example by Ramey at al. (1975) or Sabet (1991) - is used for evaluation of permeability and skin in the situations depicted above. This method requires construction of a $p_{D}$ vs. $t_{D} / c_{D}$ curve using the measured data and fitting this curve to one of a family of theoretical curves. Each theoretical curve was constructed for known value of permeability and skin. The calculation of the skin effect requires the selection of a "match point" and uses its' coordinates to evaluate $S$. The theoretical type curves are constructed for the early time data, late time data, and for the whole period of flow. The permeability and skin calculated using the selected theoretical curves should not differ much between each curve.

The "type curve" method which is used for the analysis of DST flow period data is thoroughly verified and well-known to reservoir engineers and thus its theoretical foundation will not be discussed here. In some instances the standard well-testing methods such as the drawdown test or pressure build-up test cannot be used if they are required to produce some reservoir fluid (which can be restricted by pollution control regulations) or the well does not flow to the surface. In such cases, the recorded relation of downhole pressure vs. time (DST flow period data) for a period before the fluid reaches the surface is the only source which can give us information about reservoir parameters and use of the "type curve" fitting method is the only option. Besides permeability and skin no additional information can be attained using the "type curve" method.

The major disadvantage of the "type curve" fitting method is the uncertainty regarding selection of a theoretical curve that fits in with the one constructed using the measured data because all "type curves" looks alike and selection of a wrong one may yield results which are inaccurate at best. In this study, we will present an alternative method for interpretation of DST flow period data that can be also used for the interpretation of the pressure vs. time behavior in low pressure water wells after some fluid was added or removed from the well. Below you will also find the comparison of results from both of the methods being discussed.

The enclosed examples concern the most important case i.e. interpretation of DST flow period data. The mathematical model which is the basis of the herein presented technique of DST data interpretation is described in Szpunar (2001), where the detailed derivation of final formulas is presented including the model assumptions and the initial and boundary conditions. The technique was fully developed in Szpunar and Budak's paper (2012) where application to DST data was demonstrated including calculation of wellbore zone permeability and depth of permeability impairment/improvement. All examples of interpretation of the DST flow period data analyzed using the proposed technique will be accompanied by examples of interpretation of the same data using the "type curve" fitting method in order to verify the results. From among over one hundred examples of DST flow period data analyzed we selected 30 for which we were sure that the pressure drop during fluid flow is too low to affect pressures measured opposite to the reservoir which is assumed to be hydrostatic. Such a comparison between the results of two methods has never been done before. The method being discussed was elaborated by the authors of this paper and we try to present its usability herein. It was also discussed in Faruk Civan's book (2015).

\section{Technique for interpretation of DST flow period data}

According to Szpunar (2001) the equation describing the dimensionless pressure vs. time relation for the time period from the start of flow (from the moment the DST valve is opened) to the moment when fluid starts to outflow from the well (or fluid level stabilize within the well) is presented as the following Equation: 


$$
\log p_{D}=-(5.11)\left(10^{-7}\right) \frac{k h \rho}{r_{w}^{2} \mu} \frac{1}{\ddot{u}} t-\log \left(1-\frac{S}{\ddot{u}}\right)
$$

where

$$
p_{D}=\frac{p(t)-p_{o}}{p_{1}-p_{o}}
$$

$p(t)$ - pressure at the bore hole wall [at],

$p_{1}$ - reservoir pressure [at],

$p_{o}$ - initial pressure opposite the reservoir at the moment the

DST master valve is opened (for $t=0$ ) [at],

$k$ - permeability of reservoir [mD],

$h$ - thickness of the reservoir [m],

$\rho-$ liquid density $\left[\mathrm{g} / \mathrm{cm}^{3}\right]$,

$r_{w}$ - inside radius of the DST flow pipe [m],

$\mu-$ liquid viscosity [cP],

$t$ - time [min],

$S$ - skin effect [dimensionless].

It has been demonstrated in Szpunar (2001) that the $\ddot{u} \in\left(\frac{1}{2}, \infty\right)$ is the larger root of the following Equation:

$$
u=\frac{1}{2} \ln u-\frac{1}{2} \ln m
$$

where

$$
m=0.049\left(\frac{r_{o}}{r_{w}}\right)^{2} h \phi \rho c_{t}
$$

$\phi$ - porosity of the reservoir,

$r_{o}$ - well radius [m],

$c_{t}$ - total compressibility [1/at].

The $\ddot{u}$ is computed using the simple iteration procedure shown below:

Let any value of $u \in\left(\frac{1}{2}, \infty\right)$ be the first approximation of $\ddot{u}$. We have:

$$
u_{i+1}=\frac{1}{2} \ln u_{i}-\frac{1}{2} \ln \ln m \text { for } i=0, \ldots n
$$

If $u_{i+1}-u_{i}<\varepsilon$, where $\varepsilon$ is the assumed small value, then $u_{i}=\ddot{u}$. Usually a few iterations are sufficient to calculate $\ddot{u}$.

The Equation (1) indicates that in a $\log p_{D}$ vs. $t$ rectangular system of coordinates, the measured data should plot along the straight line whose slope is:

$$
a=(5.11)\left(10^{-7}\right) \frac{k h \rho}{r_{w}^{2} \mu} \frac{1}{\ddot{u}}
$$

and that this straight line will cross the $\log p_{D}$ axis at $t=0$ in point $b$ where

$$
b=\log \left(1-\frac{S}{\ddot{u}}\right)
$$

During the fluid flow to the DST tester the $p_{D}$ values are measured for various times $t$. The $a$ and $b$ values may be evaluated using the least squares method i.e. finding the minimum of the following Equation:

$$
k=\sum_{i=1}^{N}\left(\log p_{D}+a t_{i}+b\right)^{2}
$$

It might be easily proved that $a$ and $b$ are given by:

$$
\begin{gathered}
a=\frac{\sum_{i=1}^{N} \log p_{D} \sum_{i=1}^{N} t_{i}-N \sum_{i=1}^{N} t_{i} \log p_{D_{i}}}{N \sum_{i=1}^{N} t_{i}^{2}-\left(\sum_{i=1}^{N} t_{i}\right)^{2}} \\
b=\frac{\sum_{i=1}^{N} t_{i} \sum_{i=1}^{N} t_{i} \log p_{D_{i}}-\sum_{i=1}^{N} \log p_{D_{i}} \sum_{i=1}^{N} t_{i}}{N \sum_{i=1}^{N} t_{i}^{2}-\left(\sum_{i=1}^{N} t_{i}\right)^{2}}
\end{gathered}
$$

Comparing Equations (8) and (9) with Equations (5) and (6) respectively, the permeability and skin may be computed by solving the obtained Equations. In Equations (8) and (9), $N$ is the total number of measurements and $p_{D i}$ and $t_{i}$ are the results of $i$-th measurement. In practice, the Excel calculation chart is used to compute $a$ and $b$ instead of using Equations (8) and (9).

For nearly all of the analyzed case studies it has been observed that the $\log p_{D}$ vs. $t$ plot is linear for the initial and final period of flow and that both flow periods are separated by a transition period, for which the $\log p_{D}$ vs. $t$ relation does not follow the linear trend (Szpunar and Budak, 2012). This observation may be explained by the difference between the permeability of the well bore zone and permeability of the reservoir using the following reasoning:

At the start of the period of flow only the zone within the immediate vicinity of the well is affected by the pressure change and the slope of $\log p_{D}$ vs. $t$ is indicative of permeability of the well bore zone. The $\log p_{D}$ vs. $t$ relation is linear like when the reservoir is homogenous with no skin. As the flow continues, more and more volume of the reservoir is affected by pressure change which causes the deviation of the straight line because its' shape depends both on the permeability of the well bore zone and the permeability of the reservoir with increasing participation of the latter. For a long time of flow the $\log p_{D}$ vs. $t$ data again plot along the straight line whose slope is usually different than those for a short time of flow.

For the long time of flow the volume of the reservoir affected by pressure change is considerably larger than the volume of the well bore zone and the impact of the well bore zone permeability on pressure behavior becomes negligible. The slope of the $\log p_{D}$ vs. $t$ line for the long time of flow is indicative of the permeability of the reservoir and the point of intersection 
of this line extended to the $\log p_{D}$ axis for $t=0$, given as $b$, enables calculation of the skin as indicated by Equation (1).

If the permeability of the well bore zone and the permeability of the reservoir - as well as the skin value - are known we can provide the approximated extent of the zone with improved/impaired permeability using the well-known Equation:

$$
\Delta r=r_{o}\left(e^{\frac{s k_{s}}{k-k_{s}}}-1\right)
$$

The Equation (10) assumes the sharp transition between reservoir properties at $\Delta r$ which is rather not true. The linear trajectory of the $\log p_{D}$ vs. $t$ relation - with no transition period - indicates "no skin" or "too short a time of flow", i.e. the time of flow was too short to affect the pressure within the more distant part of the reservoir.

\section{Results - examples}

Below you will find examples of interpretation of the DST flow period data (slug test data) using the technique presented in Szpunar (2001) and the comparison of the results obtained with those achieved using the "type curve" method that illustrate the problems accompanying selection of the right curve. All type curves are taken from Sabet (1991).

Example 1: Well O-3 II (Fig. 1-5)

Well radius: $157 \mathrm{~mm}$

Internal radius of tubing: $70.2 \mathrm{~mm}$

Thickness of reservoir: $3 \mathrm{~m}$

Porosity: $15 \%$

Reservoir pressure: $15.29 \mathrm{MPa}$

Liquid density: $1074 \mathrm{~kg} / \mathrm{m}^{3}$

Liquid viscosity: $0.78 \mathrm{mPas}$

Total compressibility: $0.000361 / \mathrm{MPa}$

Initial flowing pressure: $12.21 \mathrm{MPa}$

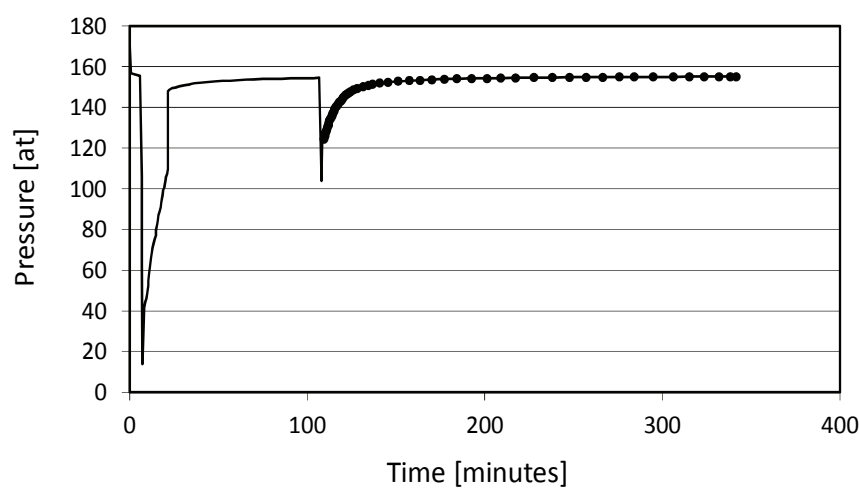

Fig. 1. DST build up pressure vs. time curve for the O-3 II well Rys. 1. Krzywa odbudowy ciśnienia w funkcji czasu dla odwiertu O-3 II

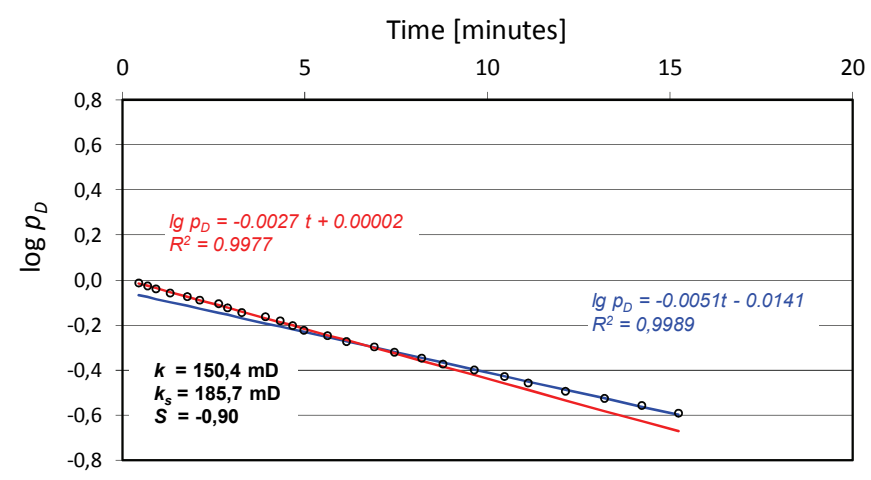

Fig. 2. $\log p_{D}$ vs. time curve for the O-3 II well

Rys. 2. Zależność $\log p_{D}$ od czasu dla odwiertu O-3II

\section{Results:}

Permeability of reservoir: $150.4 \mathrm{mD}$

Permeability of the wellbore zone: $185.7 \mathrm{mD}$

Skin effect: -0.90

Depth of permeability improvement/impairment: $9.01 \mathrm{~m}$

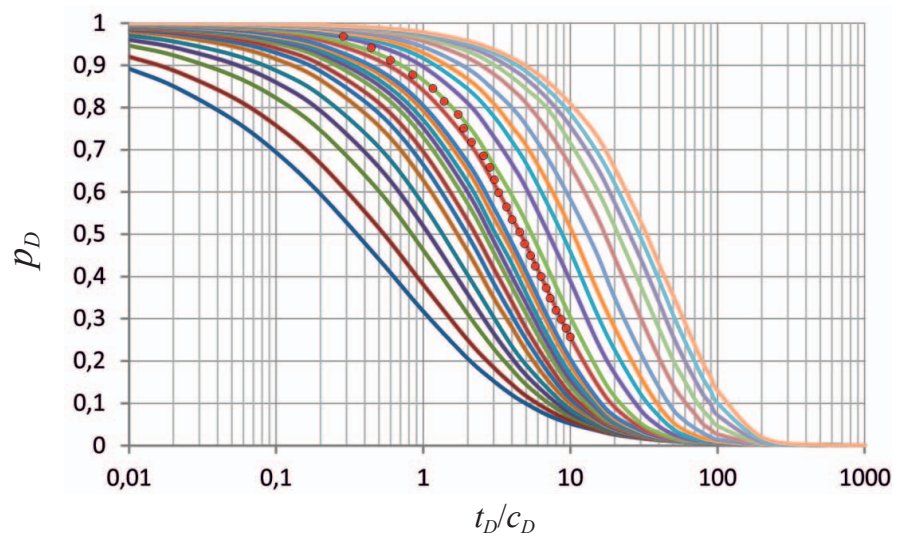

Fig. 3. $p_{D}$ vs. $t_{D} / c_{D}$ type curve for the whole flow period for the O-3 II well $(k=165.30 \mathrm{mD}, S=0.26)$

Rys. 3. Krzywa $p_{D}$ vs. $t_{D} / c_{D}$ dla całego okresu odbudowy w odwiercie O-3 II $(k=165,30 \mathrm{mD}, S=0,26)$

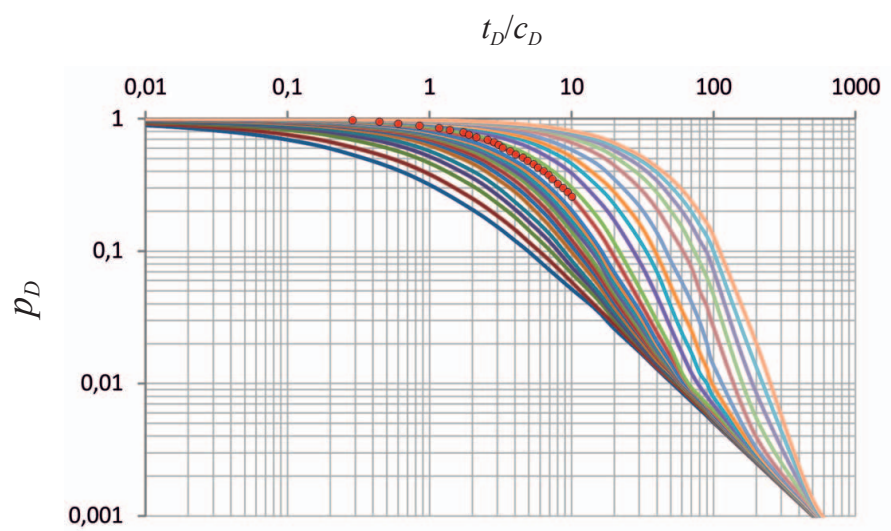

Fig. 4. $p_{D}$ vs. $t_{D} / c_{D}$ type curve for the late time data for the O-3 II well $(k=167.71 \mathrm{mD}, S=0.26)$

Rys. 4. Krzywa $p_{D}$ vs. $t_{D} / c_{D}$ dla późnych czasów odbudowy w odwiercie O-3 II $(k=167,71 \mathrm{mD}, S=0,26)$ 


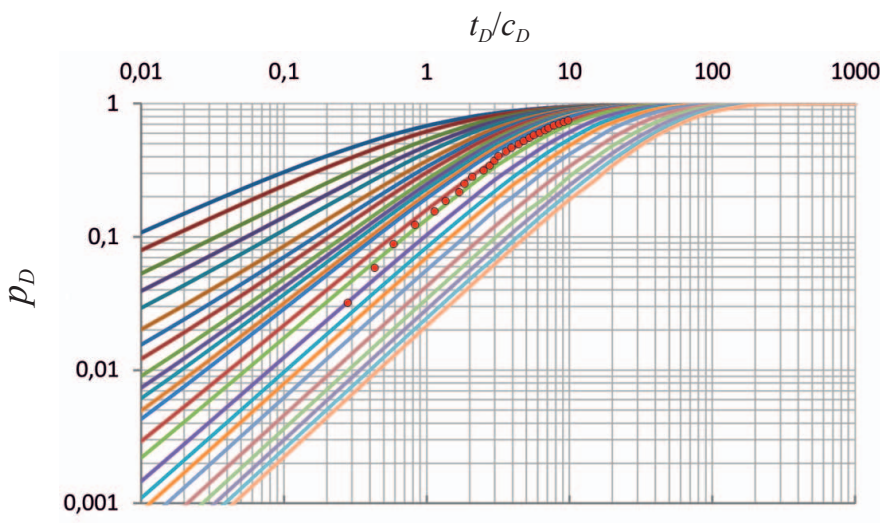

Fig. 5. $p_{D}$ vs. $t_{D} / c_{D}$ type curve for the early time data for the O-3 II well $(k=165.37 \mathrm{mD}, S=0.26)$

Rys. 5. Krzywa $p_{D}$ vs. $t_{D} / c_{D}$ dla wczesnych czasów odbudowy w odwiercie O-3 II $(k=165,37 \mathrm{mD}, S=0,26)$

\section{Example 2: Well W-3 IIA (Fig. 6-10)}

Well radius: $216 \mathrm{~mm}$

Internal radius of tubing: $84.8 \mathrm{~mm}$

Thickness of reservoir: $8 \mathrm{~m}$

Porosity: $10 \%$

Reservoir pressure: $12.48 \mathrm{MPa}$

Liquid density: $1065 \mathrm{~kg} / \mathrm{m}^{3}$

Liquid viscosity: $2.35 \mathrm{mPas}$

Total compressibility: 0.00007 1/MPa

Initial flowing pressure: $5.47 \mathrm{MPa}$

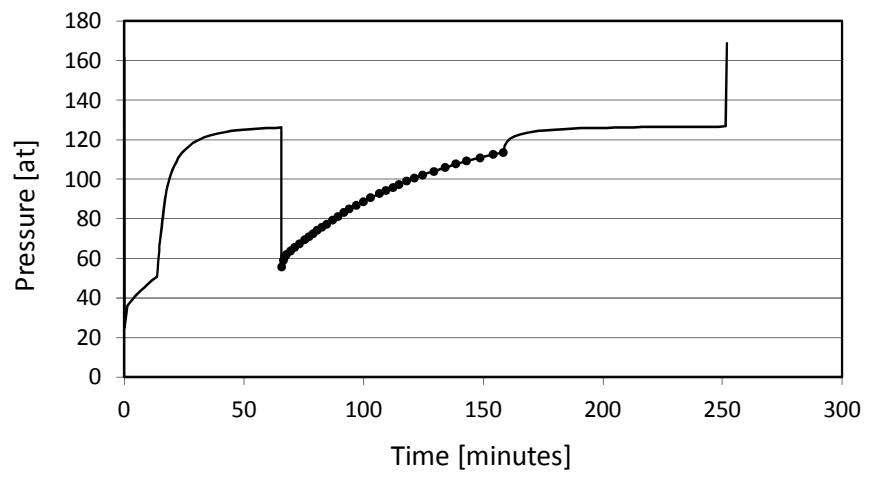

Fig. 6. DST build up pressure vs. time curve for the W-3 IIA well

Rys. 6. Krzywa odbudowy ciśnienia w funkcji czasu dla odwiertu W-3 IIA

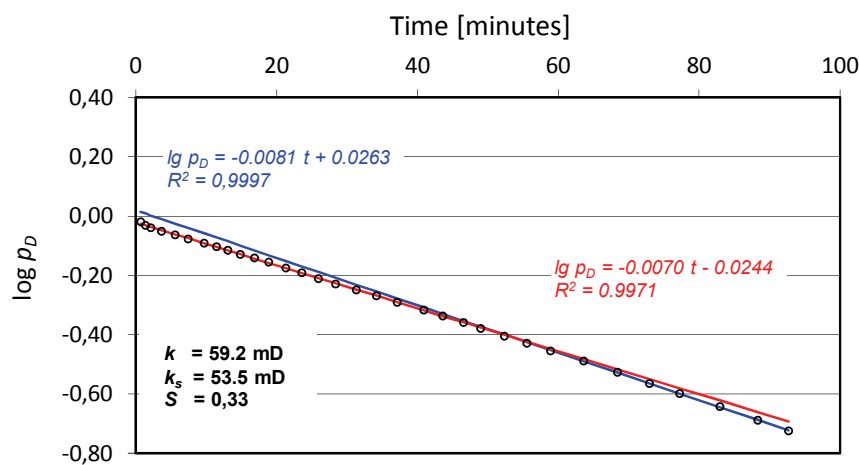

Fig. 7. $\log p_{D}$ vs. time curve for the W-3 IIA well

Rys. 7. Zależność $\log p_{D}$ od czasu dla odwiertu W-3 IIA

\section{Results:}

Permeability of reservoir: $59.2 \mathrm{mD}$

Permeability of the wellbore zone: $53.5 \mathrm{mD}$

Skin effect: 0.33

Depth of permeability improvement/impairment: $2.34 \mathrm{~m}$

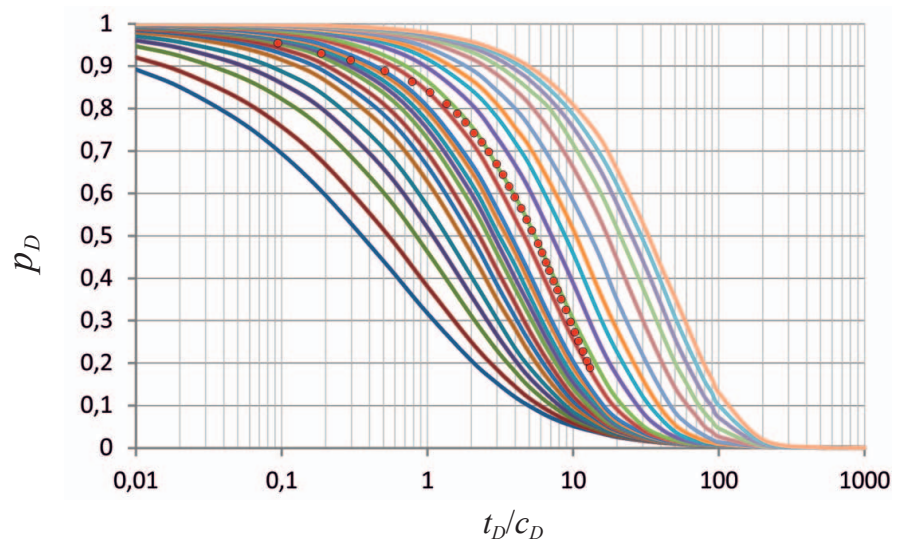

Fig. 8. $p_{D}$ vs. $t_{D} / c_{D}$ type curve for the whole flow period for the W-3 IIA well $(k=59.36 \mathrm{mD}, S=1.00)$

Rys. 8. Krzywa $p_{D}$ vs. $t_{D} / c_{D}$ dla całego okresu odbudowy w odwiercie W-3 IIA $(k=59,36 \mathrm{mD}, S=1,00)$

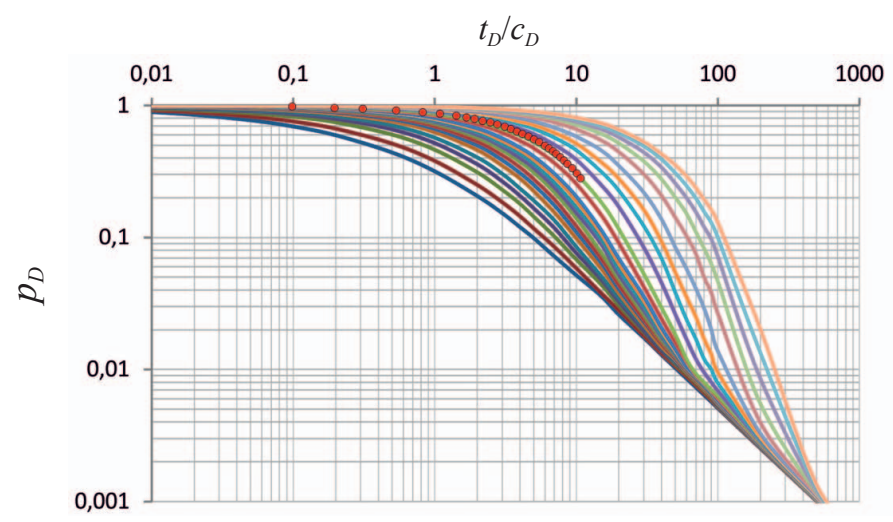

Fig. 9. $p_{D}$ vs. $t_{D} / c_{D}$ type curve for the late time data for the W-3 IIA well $(k=58.16 \mathrm{mD}, S=1.00)$

Rys. 9. Krzywa $p_{D}$ vs. $t_{D} / c_{D}$ dla późnych czasów odbudowy w odwiercie W-3 IIA $(k=58,16 \mathrm{mD}, S=1,00)$

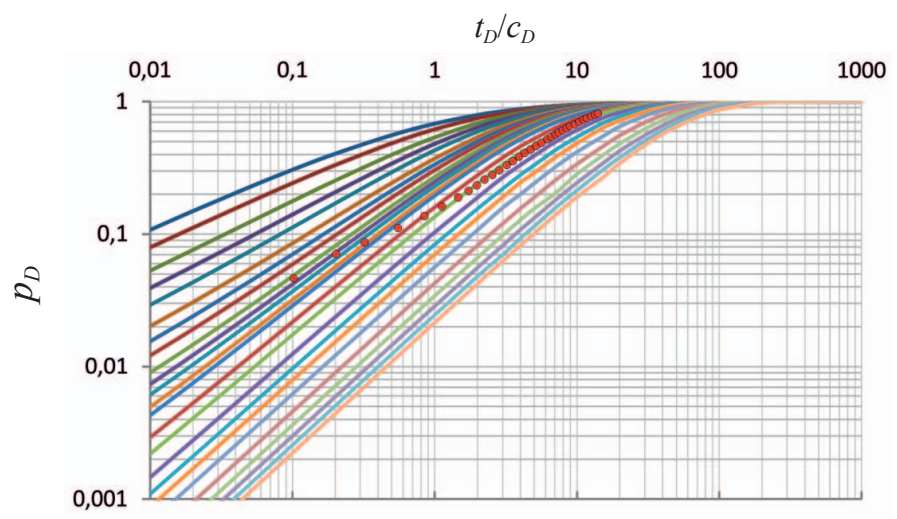

Fig. 10. $p_{D}$ vs. $t_{D} / c_{D}$ type curve for the early time data for the W-3 IIA well $(k=59.36 \mathrm{mD}, S=1.00)$

Rys. 10. Krzywa $p_{D}$ vs. $t_{D} / c_{D}$ dla wczesnych czasów odbudowy w odwiercie W-3 IIA $(k=59,36 \mathrm{mD}, S=1,00)$ 


\section{NAFTA-GAZ}

Example 3: Well P-2 IA (Fig. 11-15)

Well radius: $216 \mathrm{~mm}$

Internal radius of tubing: $97 \mathrm{~mm}$

Thickness of reservoir: $20 \mathrm{~m}$

Porosity: $10 \%$

Reservoir pressure: $12.56 \mathrm{MPa}$

Liquid density: $1040 \mathrm{~kg} / \mathrm{m}^{3}$

Liquid viscosity: $0.73 \mathrm{mPas}$

Total compressibility: $0.00041 / \mathrm{MPa}$

Initial flowing pressure: $3.90 \mathrm{MPa}$

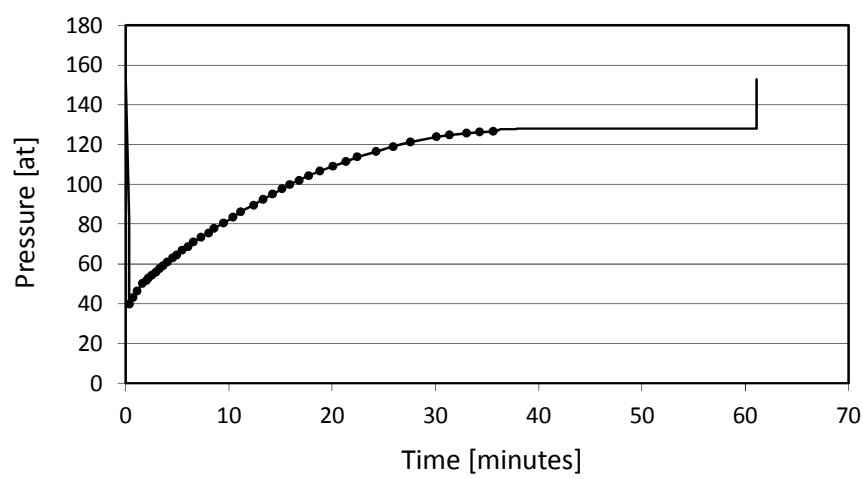

Fig. 11. DST build up pressure vs. time curve for the P-2 IA well Rys. 11. Krzywa odbudowy ciśnienia w funkcji czasu dla odwiertu P-2 IA

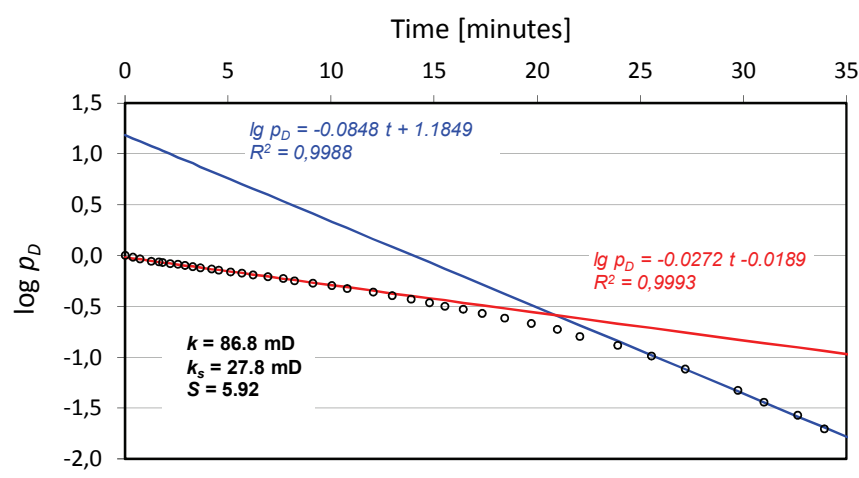

Fig. 12. $\log p_{D}$ vs. time curve for the P-2 IA well

Rys. 12. Zależność log $p_{D}$ od czasu dla odwiertu P-2 IA

\section{Results:}

Permeability of reservoir: $86.8 \mathrm{mD}$

Permeability of the wellbore zone: $27.8 \mathrm{mD}$

Skin effect: 5.92

Depth of permeability improvement/impairment: $1.66 \mathrm{~m}$

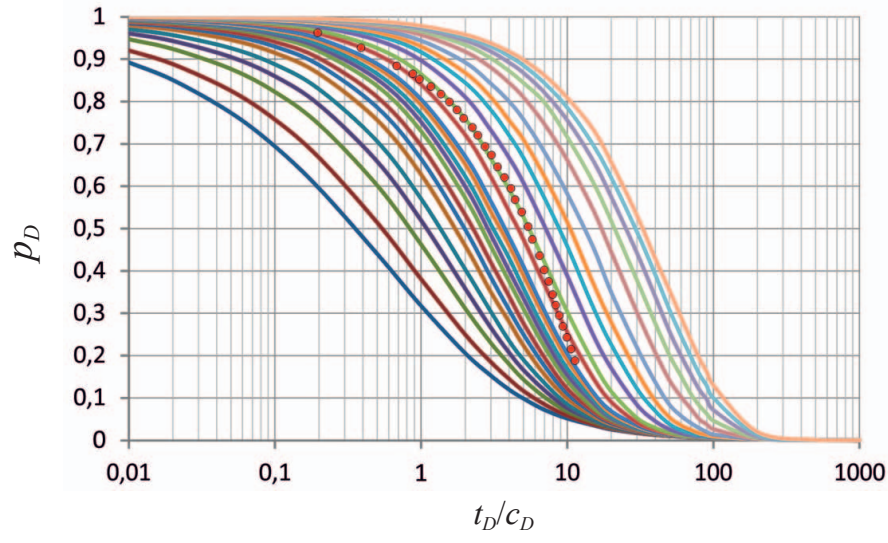

Fig. 13. $p_{D}$ vs. $t_{D} / c_{D}$ type curve for the whole flow period for the P-2 IA well $(k=68.78 \mathrm{mD}, S=1.11)$

Rys. 13. Krzywa $p_{D}$ vs. $t_{D} / c_{D}$ dla całego okresu odbudowy w odwiercie P-2 IA $(k=68,78 \mathrm{mD}, S=1,11)$

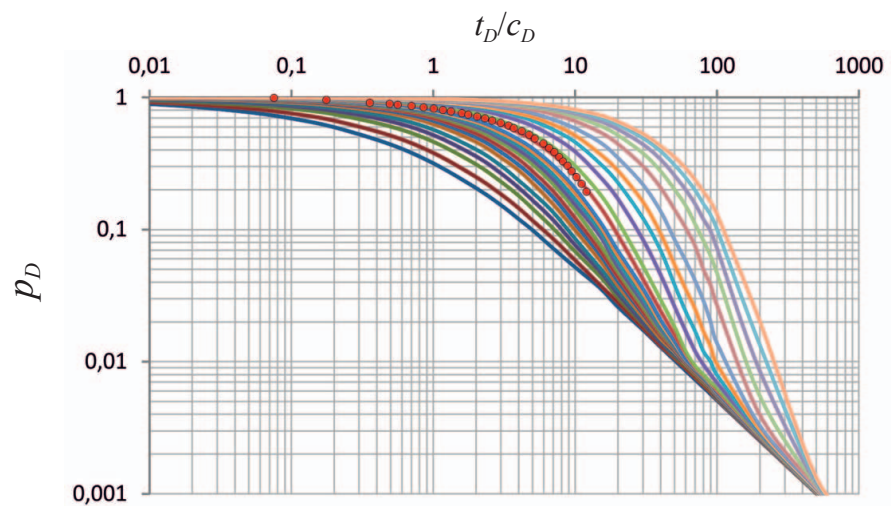

Fig. 14. $p_{D}$ vs. $t_{D} / c_{D}$ type curve for the late time data for the P-2 IA well $(k=83.85 \mathrm{mD}, S=1.11)$

Rys. 14. Krzywa $p_{D}$ vs. $t_{D} / c_{D}$ dla późnych czasów odbudowy w odwiercie P-2 IA $(k=83,85 \mathrm{mD}, S=1,11)$

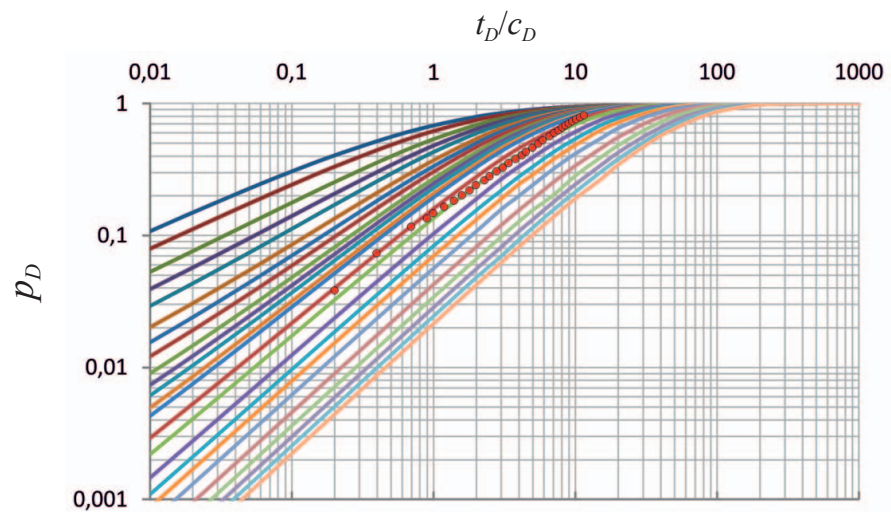

Fig. 15. $p_{D}$ vs. $t_{D} / c_{D}$ type curve for the early time data for the P-2 IA well $(k=72.14 \mathrm{mD}, S=1.11)$

Rys. 15. Krzywa $p_{D}$ vs. $t_{D} / c_{D}$ dla wczesnych czasów odbudowy w odwiercie P-2 IA $(k=72,14 \mathrm{mD}, S=1,11)$ 
Example 4: Well O-141 II (Fig. 16-20)

Well radius: $216 \mathrm{~mm}$

Internal radius of tubing: $107 \mathrm{~mm}$

Thickness of reservoir: $15 \mathrm{~m}$

Porosity: $10 \%$

Reservoir pressure: $4.94 \mathrm{MPa}$

Liquid density: $1180 \mathrm{~kg} / \mathrm{m}^{3}$

Liquid viscosity: $0.98 \mathrm{mPas}$

Total compressibility: $0.00041 / \mathrm{MPa}$

Initial flowing pressure: $1.45 \mathrm{MPa}$

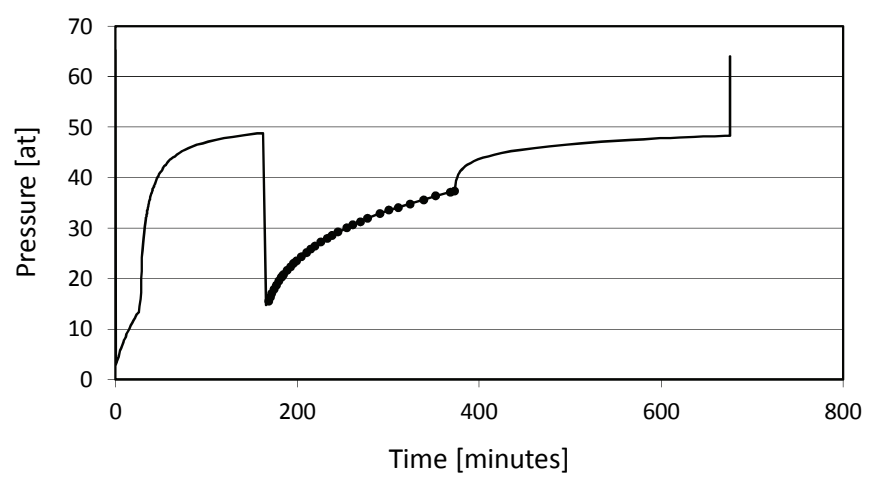

Fig. 16. DST build up pressure vs. time curve for the O-141 II well Rys. 16. Krzywa odbudowy ciśnienia w funkcji czasu dla odwiertu O-141 II

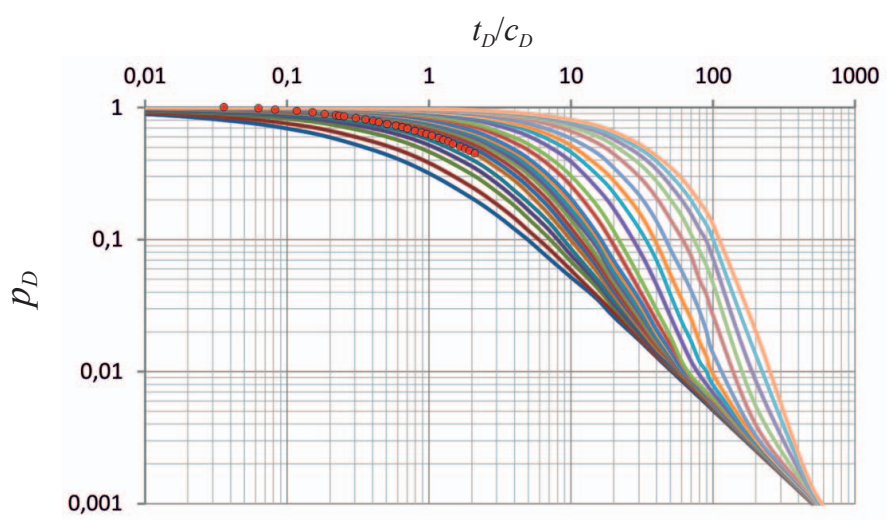

Fig. 17. $\log p_{D}$ vs. time curve for the O-141 II well

Rys. 17. Zależność $\log p_{D}$ od czasu dla odwiertu O-141 II

\section{Results:}

Permeability of reservoir: $3.2 \mathrm{mD}$

Permeability of the wellbore zone: $9.3 \mathrm{mD}$

Skin effect: -1.92

Depth of permeability improvement/impairment: $1.91 \mathrm{~m}$

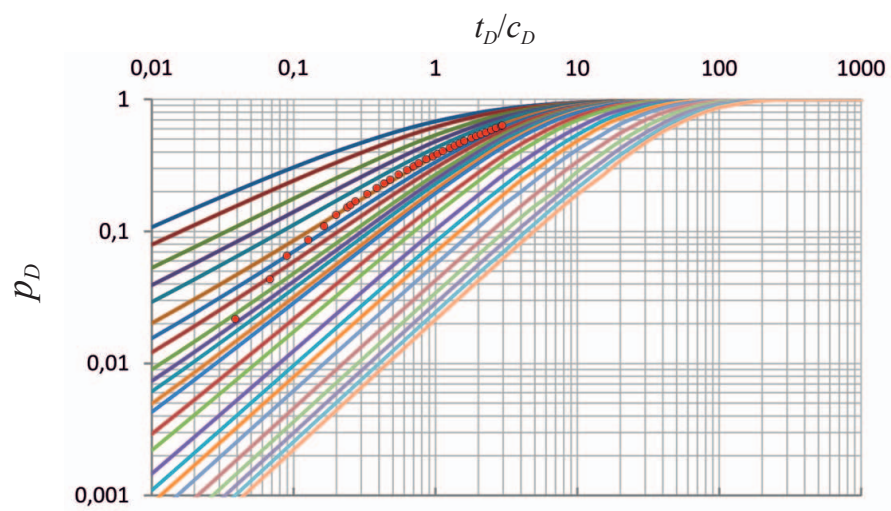

Fig. 18. $p_{D}$ vs. $t_{D} / c_{D}$ type curve for the whole flow period for the O-141 II well $(k=2.41 \mathrm{mD}, S=2.60)$

Rys. 18. Krzywa $p_{D}$ vs. $t_{D} / c_{D}$ dla całego okresu odbudowy w odwiercie O-141 II $(k=2,41 \mathrm{mD}, S=2,60)$

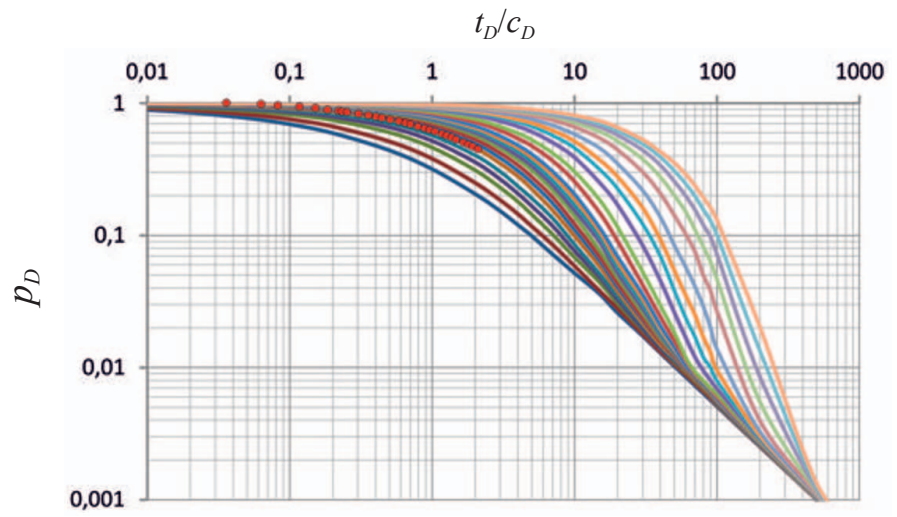

Fig. 19. $p_{D}$ vs. $t_{D} / c_{D}$ type curve for the late time data for the O-141 II well $(k=2.27 \mathrm{mD}, S=2.60)$

Rys. 19. Krzywa $p_{D}$ vs. $t_{D} / c_{D}$ dla późnych czasów odbudowy w odwiercie O-141 II $(k=2,27 \mathrm{mD}, S=2,60)$

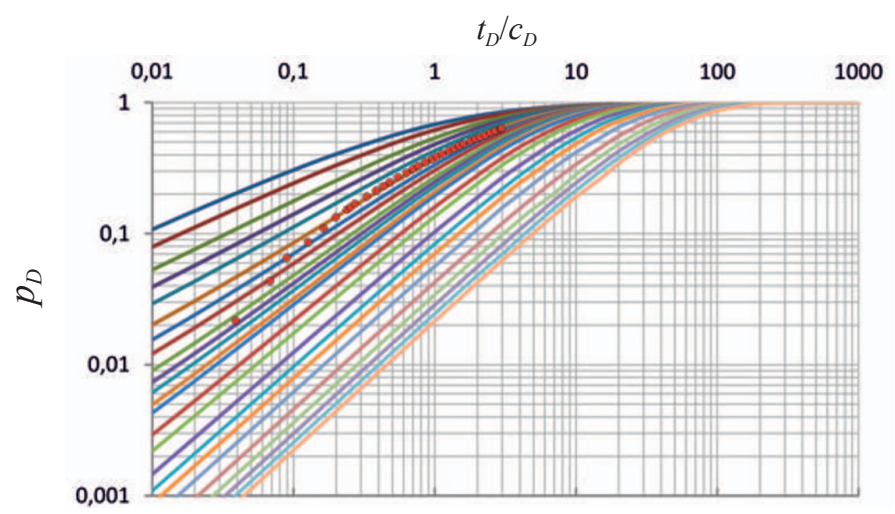

Fig. 20. $p_{D}$ vs. $t_{D} / c_{D}$ type curve for the early time data for the O-141 II well $(k=2.47 \mathrm{mD}, S=2.60)$

Rys. 20. Krzywa $p_{D}$ vs. $t_{D} / c_{D}$ dla wczesnych czasów odbudowy w odwiercie O-141 II $(k=2,47 \mathrm{mD}, S=2,60)$

Example 5: Well W-16 II (Fig. 21-25)

Well radius: $220 \mathrm{~mm}$

Internal radius of tubing: $97.6 \mathrm{~mm}$

Thickness of reservoir: $30 \mathrm{~m}$

Porosity: $7.5 \%$ 


\section{NAFTA-GAZ}

Reservoir pressure: $18.51 \mathrm{MPa}$

Liquid density: $1133 \mathrm{~kg} / \mathrm{m}^{3}$

Liquid viscosity: $0.83 \mathrm{mPas}$

Total compressibility: $0.000321 / \mathrm{MPa}$

Initial flowing pressure: $7.36 \mathrm{MPa}$

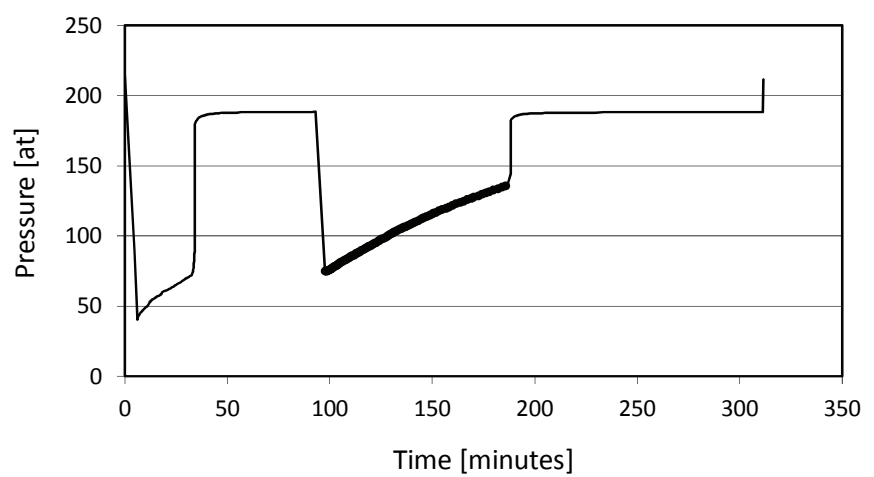

Fig. 21. DST build up pressure vs. time curve for the W-16 II well Rys. 21. Krzywa odbudowy ciśnienia w funkcji czasu dla odwiertu W-16 II

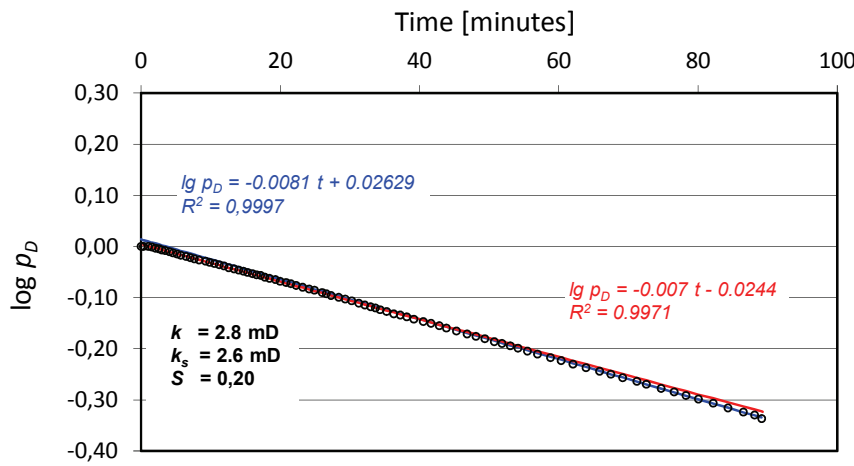

Fig. 22. $\log p_{D}$ vs. time curve for the W-16 II well

Rys. 22. Zależność log $p_{D}$ od czasu dla odwiertu W-16 II

\section{Results:}

Permeability of reservoir: $2.8 \mathrm{mD}$

Permeability of the wellbore zone: $2.6 \mathrm{mD}$

Skin effect: 0.20

Depth of permeability improvement/impairment: $2.26 \mathrm{~m}$

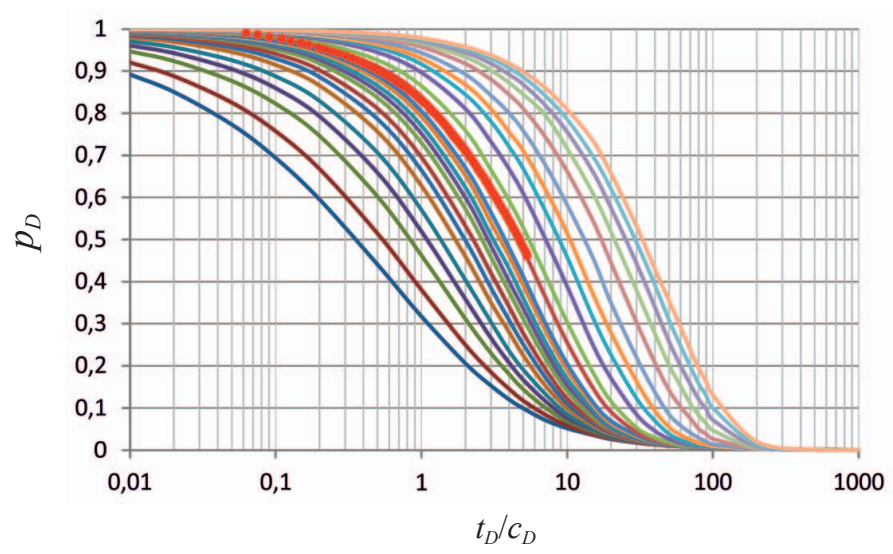

Fig. 23. $p_{D}$ vs. $t_{D} / c_{D}$ type curve for the whole flow period for the W-16 II well $(k=2.37 \mathrm{mD}, S=1.04)$

Rys. 23. Krzywa $p_{D}$ vs. $t_{D} / c_{D}$ dla całego okresu odbudowy w odwiercie W-16 II $(k=2,37 \mathrm{mD}, S=1,04)$

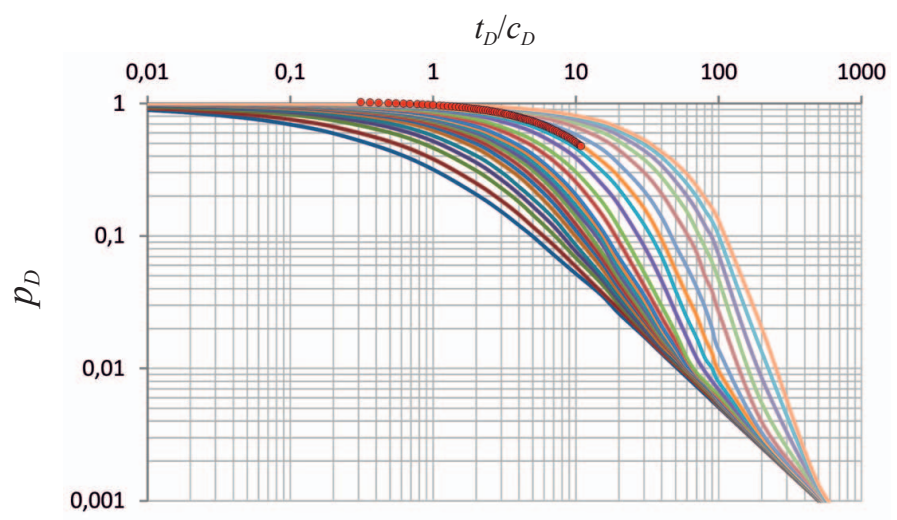

Fig. 24. $p_{D}$ vs. $t_{D} / c_{D}$ type curve for the late time data for the W-16 II well $(k=2.86 \mathrm{mD}, S=2.19)$

Rys. 24. Krzywa $p_{D}$ vs. $t_{D} / c_{D}$ dla późnych czasów odbudowy w odwiercie W-16 II $(k=2,86 \mathrm{mD}, S=2,19)$

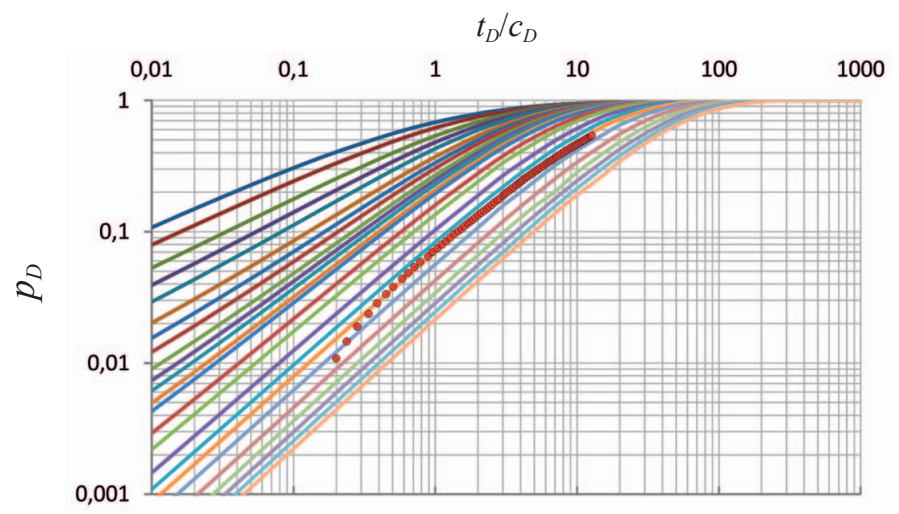

Fig. 25. $p_{D}$ vs. $t_{D} / c_{D}$ type curve for the early time data for the W-16 II well $(k=2.86 \mathrm{mD}, S=2.19)$

Rys. 25. Krzywa $p_{D}$ vs. $t_{D} / c_{D}$ dla wczesnych czasów odbudowy w odwiercie W-16 II ( $k=2,86 \mathrm{mD}, S=2,19)$ 


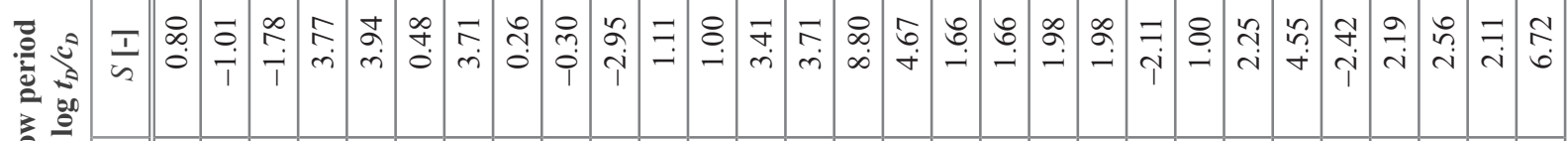

矛 当 I

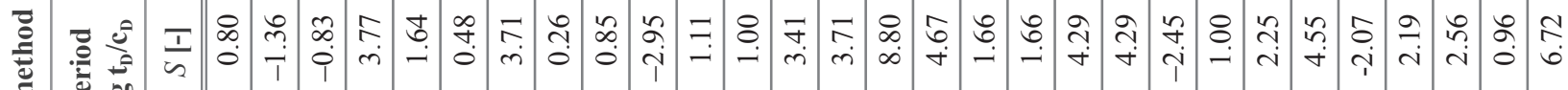
总

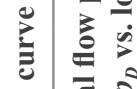

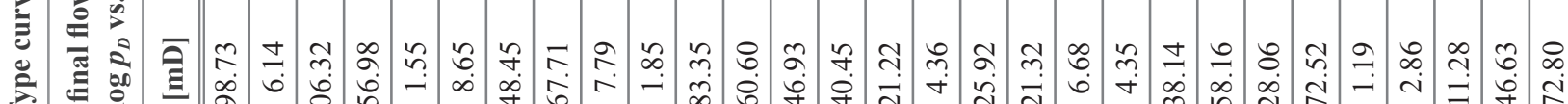

总

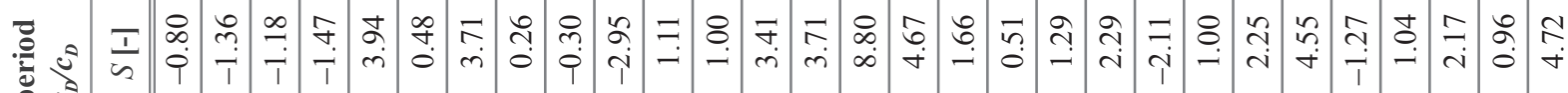
每

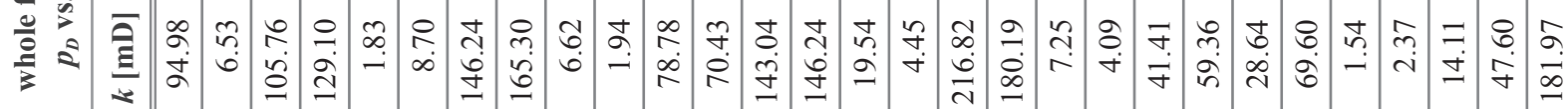

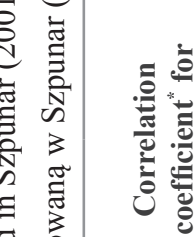

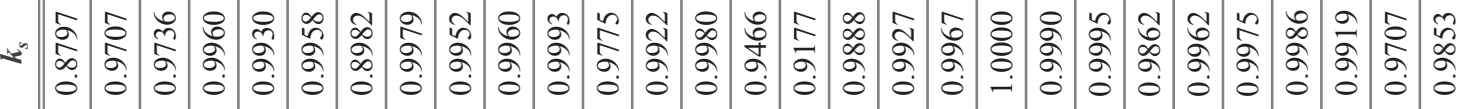

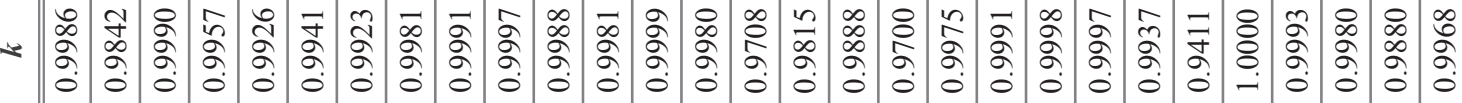

离

3.

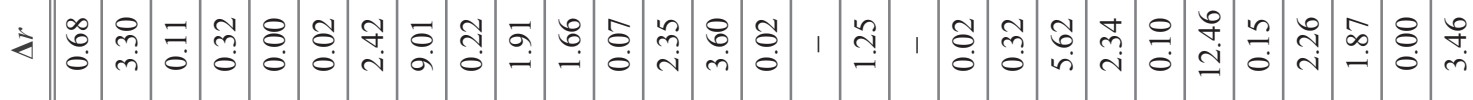

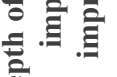

3

$\overbrace{}^{\infty}$

药

"थ

-

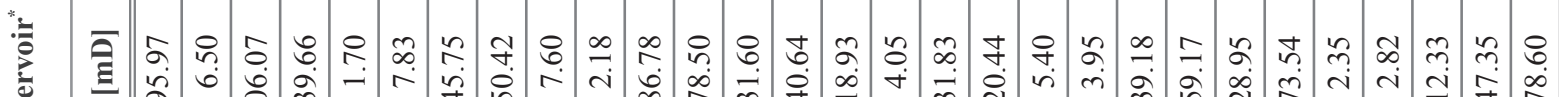

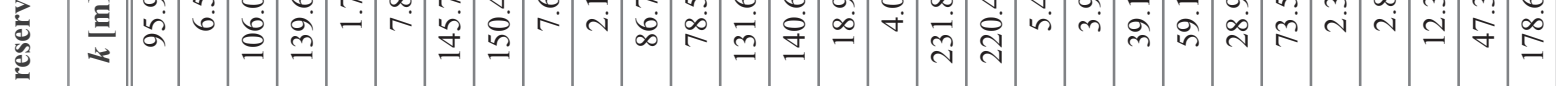




\section{Discussion}

1. There is an acceptable agreement between the permeability calculated using each of the methods discussed. One should not expect the permeabilities calculated using each of the methods to be identical.

2. The agreement between the skin factors evaluated via each of the methods is moderate, however the sign of a skin is usually the same except for a few cases in which $S$ is close to zero. One should note that the definition of a skin i.e. $\Delta p_{\text {skin }}=\left(Q_{\mu} / 2 \pi k h\right) S$ assumes constant flow rate which is not the case in the considered examples.

3. The depths of permeability impairment/improvement seem to be reasonable when compared with the data given in Amaerule and Kersey (1990) and the correlation coefficient for data required for calculation of $k$ and $k_{s}$ is high.

4. The permeability calculated using the technique presented in Szpunar (2001) is rather unambiguous contrary to the "type curve" method where one set of data may fit in with a few of the theoretical curves or might not fit in with any theoretical curve.

5. The presented technique additionally gives information on the depth of permeability impairment/improvement which is not offered by the "type curve" method, however it is of some value when the "old fashioned" stimulation jobs are planned (steam soaking, wellbore heating).

The paper was written on the basis of the statutory work entitled: Opracowanie nowej metody obliczania przepuszczalności złóż gazu na podstawie przebiegu zmian ciśnienia dennego w okresie przyplywu gazu - the work of the Oil and Gas Institute - National Research Institute commissioned by the Ministry of Science and Higher Education; order number: 0058/SI/2020, archival number: DK-4100-0046/2020.

\section{SI metric conversion factors}

$\mathrm{mD} \times 0,986923 \mathrm{E}-15=\mathrm{m}^{2}$

\section{References}

Amaerule J.O., Kersey D.G., 1990. Advantages in formation damage assessment and control strategies. Core Laboratories, Houston, Texas.

Civan F., 2015. Reservoir Formation Damage: Fundamentals, Modeling, Assessment, and Mitigation. Gulf Professional Publishing. 3 edition: 706-708. ISBN: 9780128018989.

Łętkowski P., Gołąbek A., Budak P., Szpunar T., Nowak R., Arabas J., 2016. Determination of the statistical similarity of the physicochemical measurement data of shale formations based on the methods of cluster analysis. Nafta-Gaz, 11: 910-918. DOI: 10.18668/ NG.2016.11.03.

Ramey H., Agarwal R., Martin J., 1975. Analysis of "slug test" or DST flow period data. Journal of Canadian Petroleum Technology, July-September: 37-47.

Sabet M.A., 1991. Well test analysis. Gulf Publishing Company, Houston.

Szpunar T., 2001. How to compute the permeability and skin of low pressure water zones. Journal of Canadian Petroleum Technology, 40(7): 45-51. DOI: 10.2118/01-07-03.

Szpunar T., Budak P., 2009. Interpretacja danych ciśnieniowych początkowego okresu przypływu płynu do otworu, przechodzącego przez warstwę produktywną ze szczeliną poziomą. Nafta-Gaz, 9: 686-691.

Szpunar T., Budak P., 2012. How to assess a depth of permeability impairment of the wellbore zone using drillstem-testing flow-period data. Journal of Canadian Petroleum Technology, 51(3): 215-222. DOI: 10.2118/157852-PA.

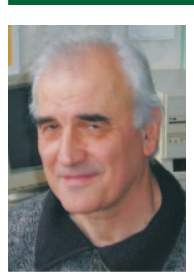

Dr inż. Tadeusz SZPUNAR

Adiunkt w Zakładzie Inżynierii Naftowej

Instytut Nafty i Gazu - Państwowy Instytut Badawczy ul. Lubicz $25 \mathrm{~A}$

31-503 Kraków

E-mail: tadeusz.szpunar@inig.pl

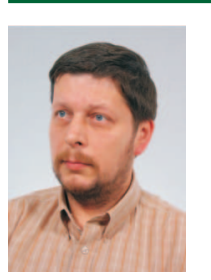

Mgr inż. Paweł BUDAK

Starszy specjalista naukowo-badawczy,

kierownik Zakładu Inżynierii Naftowej

Instytut Nafty i Gazu - Państwowy Instytut Badawczy

ul. Lubicz $25 \mathrm{~A}$

31-503 Kraków

E-mail: pawel.budak@inig.pl 